\section{Rash and pulmonary eosinophilia associated with fenbufen}

\section{G H Burton}

\section{Medicines Control Agency, Department of Health, London SW8 5NQ \\ G H Burton, MRCP, senior medical officer}

Correspondence to: Dr G H Burton, Regulatory Affairs and Product Surveillance, Upjohn Limited, West Sussex RH10 2NJ. reporting system between 1982 and 1988 .
Naproxen, phenylbutazone, sulindac, tolfenamic acid, and glafenine are the only non-steroidal anti-inflammatory drugs that have been implicated in the development of an allergic pulmonary eosinophilia..$^{1-4} I$ describe four cases in which fenbufen was associated with the development of rash and pulmonary eosinophilia. The Committee on Safety of Medicines was notified of all cases through the yellow card adverse drug reaction

\section{Case reports}

The table gives details of the patients and a summary of investigations and outcomes. All four patients were non-smokers; none had recently travelled abroad; and all had been in good general health up to the time of presentation. All had taken fenbufen for non-inflammatory osteoarthritis, and two patients (cases 3 and 4) had taken the drug for about two weeks before the onset of symptoms. The two other patients (cases 1 and 2) had taken the drug intermittently. All patients recovered clinically over one to two weeks after withdrawal of fenbufen; two patients (cases 1 and 3) were given immunosuppressants. Radiological recovery took somewhat longer except in case 4 . Rechallenge with fenbufen was not undertaken.

\section{Comment}

To my knowledge this is the first report of a pulmonary eosinophilia occurring in association with fenbufen. It is unlikely that other drugs that the patients had taken could account for the clinical events. The drugs given to one patient (case 3) at the time of presentation, though possibly associated with the isolation of Clostridium difficile from the stool, were given shortly after the onset of the illness and were unlikely to have contributed to the eosinophilia. Although investigations for organisms that cause intestinal and other tropical infectious disorders were not performed in all cases, it seems unlikely that such organisms could have been responsible for the clinical events considering that none of the patients had recently travelled to a foreign country and the rapid recovery after withdrawal of fenbufen.

The Committee on Safety of Medicines has received a further report implicating fenbufen in an acute episode of rash followed about two weeks later by malaise, acute cough, and worsening of breathlessness in a 72 year old man who had a pre-existing clinically stable idiopathic pulmonary fibrosis. The illness was accompanied by additional patchy shadowing in the chest radiograph and a peripheral blood eosinophilia of $2 \cdot 1 \times 10^{9} / 1$. No infective organism was identified. Clinical recovery and resolution of the eosinophilia ensued over the following four weeks.

All of the patients reported on in the present study presented with a generalised systemic illness accompanied by dry cough, breathlessness, pulmonary infiltrates on chest radiography, and appreciable peripheral blood eosinophilia consistent with a diagnosis of pulmonary eosinophilia. The time interval from the start of treatment to the onset of the illness in two of the cases was two weeks, which is consistent with previous reports. ${ }^{12}$ The appearance at the outset of the illness of a florid, widespread erythematous rash was interesting: only one of the published reports implicating other non-steroidal anti-inflammatory drugs in pulmonary eosinophilia has mentioned the occurrence of a preceding rash. ${ }^{5}$ Review of all the yellow card reports of associations between nonsteroidal anti-inflammatory drugs and interstitial lung disorders disclosed a single case of pulmonary eosinophilia preceded by an acute urticaria associated with diclofenac.

Results of investigations in and details of four patients with rash and pulmonary toxicity after taking fenbufen

\begin{tabular}{|c|c|c|c|c|}
\hline & Case 1 & Case 2 & Case 3 & Case 4 \\
\hline Sex, age (years) & $M, 72$ & $\mathrm{~F}, 73$ & $M, 85$ & $M, 68$ \\
\hline Indication for use & Hip joint pain & $\begin{array}{l}\text { Osteoarthrosis of hands, } \\
\text { hips, and knees }\end{array}$ & Osteoarthrosis of knees & Back and neck pain \\
\hline Duration of use & $\begin{array}{l}\text { Intermittent for three } \\
\text { months }\end{array}$ & $\begin{array}{l}\text { Intermittent for several } \\
\text { months }\end{array}$ & Two to three weeks & Two weeks \\
\hline Daily dose (mg) & 600 & 900 & 900 & 900 \\
\hline Other medical conditions & None & Palpitations & Mild untreated hypertension & None \\
\hline Concomitant medication & None & $\begin{array}{l}\text { Propranolol for } 12 \text { months, } \\
\text { temazepam }\end{array}$ & $\begin{array}{l}\text { Ampicillin and frusemide at } \\
\text { time of presentation }\end{array}$ & Paracetamol \\
\hline Presenting symptoms & $\begin{array}{l}\text { Rash then dry cough, } \\
\text { breathlessness, malaise, } \\
\text { fever }\end{array}$ & $\begin{array}{l}\text { Erythematous rash then dry } \\
\text { cough, fever, malaise }\end{array}$ & $\begin{array}{l}\text { Rash then thirst, malaise, } \\
\text { breathlessness, fever, } \\
\text { diarrhoea }\end{array}$ & $\begin{array}{l}\text { Blistering rash with dry } \\
\text { cough, breathlessness, } \\
\text { fever, wheezing, and } \\
\text { nausea }\end{array}$ \\
\hline Radiology & $\begin{array}{l}\text { Dense bilateral alveolar } \\
\text { shadowing }\end{array}$ & $\begin{array}{l}\text { Widespread bilateral } \\
\text { infiltrates }\end{array}$ & $\begin{array}{l}\text { Bilateral basal shadows with } \\
\text { progression to generalised } \\
\text { bilateral shadowing }\end{array}$ & $\begin{array}{l}\text { Ill-defined, migratory } \\
\text { shadows on serial } \\
\text { radiography (mainly mid } \\
\text { and lower zones) }\end{array}$ \\
\hline \multicolumn{5}{|l|}{ Haematology: } \\
\hline Haemoglobin $(\mathrm{g} / \mathrm{l})$ & 147 & 145 & 162 & 128 \\
\hline White cell count $\left(\times 10^{*} / 1\right)$ & $22 \cdot 0$ & $10 \cdot 7$ & $32 \cdot 0$ & $16 \cdot 5$ \\
\hline Eosinophil count $\left(\times 10^{4} / 1\right)$ & $3 \cdot 5$ & $1 \cdot 7$ & $8 \cdot 0$ & $4 \cdot 0$ \\
\hline Lung function & $\begin{array}{l}\text { Reduced lung volumes and } \\
\text { transfer factor }\end{array}$ & $\begin{array}{l}\text { Results of airways tests, } \\
\text { lung volumes, and gas } \\
\text { transfer normal }\end{array}$ & Not tested & Normal gas transfer \\
\hline Other tests & $\begin{array}{l}\text { Antinuclear factor: negative } \\
\text { Rheumatoid factor: negative } \\
\text { Legionella antibody titre: } \\
\text { not raised }\end{array}$ & $\begin{array}{l}\text { Aspergillus precipitins: } \\
\text { negative } \\
\text { IgE normal }\end{array}$ & $\begin{array}{l}\text { Clostridium difficile isolated } \\
\text { from stool at time of } \\
\text { eosinophilia. No parasites }\end{array}$ & $\begin{array}{l}\text { Aspergillus precipitins: } \\
\text { negative } \\
\text { Sputum culture: no growth } \\
\text { Stool: no parasites or ova }\end{array}$ \\
\hline $\begin{array}{l}\text { Progress after stopping taking } \\
\text { fenbufen }\end{array}$ & $\begin{array}{l}\text { All radiological, } \\
\text { haematological, and } \\
\text { lung function variables } \\
\text { improved within one week } \\
\text { taking azathioprine and } \\
\text { prednisolone and were } \\
\text { normal four months later }\end{array}$ & $\begin{array}{l}\text { Complete clinical and } \\
\text { radiological recovery at six } \\
\text { weeks, with eosinophil } \\
\text { count of } 0.66 \times 10^{4} / 1\end{array}$ & $\begin{array}{l}\text { Full clinical, radiological, } \\
\text { and haematological } \\
\text { recovery occurred over one } \\
\text { week taking } 15 \mathrm{mg} \\
\text { prednisolone daily }\end{array}$ & $\begin{array}{l}\text { Complete recovery in two } \\
\text { weeks }\end{array}$ \\
\hline
\end{tabular}


The cases described in the present report implicate fenbufen in causing an adverse reaction that presents as a florid rash followed by a severe, short lived reversible illness whose characteristic feature is a pulmonary eosinophilia.

I thank the Committee on Safety of Medicines for permission to report these cases and the doctors who originally submitted the reports for providing further clinical details.
1 O'Brien WM, Bagby GF. Rare adverse reactions to non-steroidal antiinflammatory drugs. F Rheumatol 1985;12:13-20.

Flint KC, Johnson NM. Pulmonary eosinophilia associated with naproxen therapy. F $R$ Soc Med 1987;80:120-1.

Stromberg C, Palva E, Alhava E, Aranko K, Idanpaan-Haikkila J. Pulmonary infiltrations induced by tolfenamic acid. Lancet 1987;ii:685.

4 Gheysens B, Van Miegham W. Pulmonary infiltrates with eosinophilia due to glafenine. Eur F Respir Dis 1984;65:456-9.

Chuck AJ, Wilcox M, Bossingham DH. Fenbufen-associated pneumonitis. Br f R Reumatol 1987;26:475-6.

(Accepted 12 September 1989)
Prince of Wales Hospital, Chinese University of Hong Kong, Shatin, New Territories, Hong Kong S Michael Griffin, FRCS, visiting lecturer in surgery S C Sydney Chung, MD, senior lecturer in surgery Joseph W C Leung, MD, senior lecturer in medicine Arthur K C Li, MD, professor of surgery

Correspondence to: Professor Li.

\section{Effect of intranasal oxygen on hypoxia and tachycardia during endoscopic cholangiopancreatography}

\author{
S Michael Griffin, S C Sydney Chung, \\ Joseph W C Leung, Arthur K C Li
}

Most patients tolerate endoscopic procedures well, although complications occur occasionally. Cardiopulmonary complications are the commonest and occur once in every 1600 investigations. ' We found that $44 \%$ of patients who had endoscopic retrograde cholangiopancreatography became hypoxic. ${ }^{2}$ Factors that contribute to hypoxia include advancing age, preexisting lung disease, increasing intravenous sedation, and the diameter of the endoscope. ${ }^{34}$ We carried out a randomised controlled study to assess whether administration of oxygen intranasally prevents such hypoxia.

\section{Patients, methods, and results}

We studied 80 consecutive patients undergoing elective endoscopic cholangiopancreatography, who were randomised to receive intranasal oxygen or serve as controls. Pulse oximetry was performed during the procedure with an Oxyshuttle oximeter and Transend strip recorder (Sensorimedics) with the sensor attached to an index finger. Blood pressure was measured at one minute intervals with a Dinamap monitor. Patients lay supine for one minute to establish baseline values and then turned to the prone position. The throat was sprayed with local anaesthetic, and intravenous diazepam and pethidine were administered at doses left to the endoscopist's discretion. Endoscopy was started one minute later. Oxygen $(4.5 \mathrm{l} / \mathrm{min})$ was administered intranasally to the patients randomised to receive it as soon as they were prone. Age, weight, doses of diazepam and pethidine, and length of procedure were subjected to multiple regression analysis to determine predictors of hypoxia, tachycardia, and hypotension.

Forty one patients (19 men, 22 women) served as controls and 39 (21 men, 18 women) were given oxygen. The two groups were similar in age (mean (SEM) $60 \cdot 5(2 \cdot 2) v 61 \cdot 0(2 \cdot 6))$, weight $(55 \cdot 8(1 \cdot 3) v 52 \cdot 6$ $(1 \cdot 6) \mathrm{kg}$ ), duration of procedure $(28 \cdot 2(2 \cdot 8) v 27 \cdot 8(2 \cdot 4)$ $\mathrm{min})$, and doses of pethidine $(25.8(1.6) v 23.4(1.5)$ $\mathrm{mg})$ and diazepam $(4 \cdot 6(0.3) v 4 \cdot 1(0 \cdot 3) \mathrm{mg})$. The incidence of cardiac disease (five $v$ seven patients) and of previous respiratory infection ( $19 v 20$ patients) were comparable between the two groups.

The figure shows mean oxygen saturation in the two groups. At the start of endoscopy oxygen saturation in both groups fell sharply and then rose. Mean oxygen saturation was higher throughout the procedure in the patients who received oxygen. Oxygen saturation dropped below $90 \%$ for more than 60 seconds at some point during the procedure in 21 controls and four patients given oxygen $(\mathbf{p}<0.001$, Fisher's exact test). In three patients (two controls and one given oxygen) it fell below $80 \%$, but only one of these patients was cyanosed. These patients received naloxone.

No significant difference in pulse rate or blood pressure was detected between the controls and the group given oxygen, but those patients with oxygen saturations below $90 \%$ had a significantly higher pulse rate than those who were not hypoxic $(\mathrm{p}<0.05)$. Increasing age correlated with a lower oxygen saturation in both groups (group given oxygen $\mathrm{p}<0.01, \mathrm{r}=0.512$; controls $\mathrm{p}<0.01, \mathrm{r}=0.464)$. Increasing dose of pethidine correlated with desaturation only in the control group $(\mathrm{p}<0.02, r=0.574)$. Body weight, length of procedure, and dose of diazepam given did not show a positive correlation.

\section{Comment}

Compared with gastroscopy endoscopic retrograde cholangiopancreatography poses several problems. Patients undergoing the procedure are normally older; a duodenoscope is larger than a gastroscope; the procedure is more complicated, is more unpleasant, and may take longer; heavier sedation may be necessary; and the patient is obscured by the $x$ ray machine, making monitoring more difficult.

We found that hypoxia was common during endoscopic retrograde cholangiopancreatography and occurred within the first 15 minutes; tachycardia occurred during these hypoxic episodes, suggesting that the oxygen desaturation is clinically important. Oxygen desaturation associated with tachycardia can result in myocardial ischaemia in patients with borderline coronary perfusion. ${ }^{5}$ The hypoxia during endoscopic retrograde cholangiopancreatography was prevented in all but four of 39 patients given intranasal oxygen at a dose of $4.5 \mathrm{l} / \mathrm{min}$. Monitoring of pulse

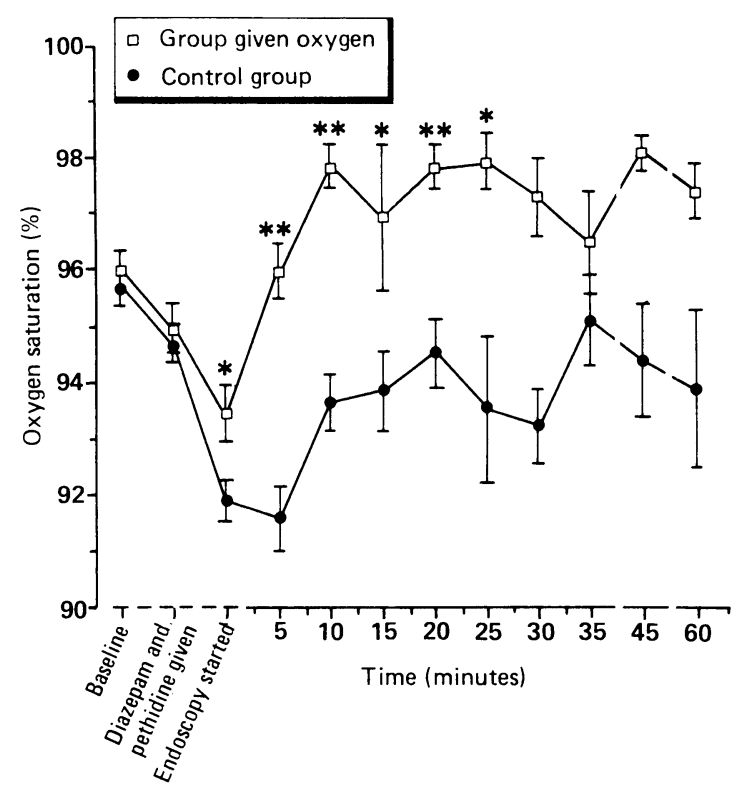

Mean (SEM) oxygen saturation in 39 patients given intranasal oxygen and 41 controls during endoscopic retrograde cholangiopancreatography. ${ }^{\star} p<0.01 ;{ }^{\star \star} p<0.001$ 